\title{
Optimasi Tween 80 dan Etanol pada Sediaan Gel Dispersi Padat Ibuprofen Secara Simplex Lattice Design
}

\section{Optimization of Tween 80 and Ethanol in Solid Dispersion Gel Of Ibuprofen By Simplex Lattice Design}

\author{
Gabriel Jonathan Suneidesis Alpons ${ }^{1}$, Siti Aisiyah ${ }^{1}$, Nuraini Harmastuti ${ }^{1}$ \\ gabrieljonathan07@gmail.com \\ ${ }^{1}$ Program Studi S1 Farmasi, Universitas Setia Budi, Surakarta \\ Riwayat Artikel: Dikirim Desember 2020; Diterima Februari 2021; Diterbitkan Maret 2021
}

\begin{abstract}
Abstrak
Ibuprofen merupakan obat golongan Non Steroid Anti-Inflamantory Drug (NSAID) yang digunakan dalam pengobatan nyeri atau inflamasi. Metode dispersi padat dapat meningkatan kelarutan ibuprofen. Ibuprofen dibuat sediaan gel untuk menghindari efek samping. Penambahan enhancer dalam gel dapat meningkatkan penetrasi zat aktif. Penelitian ini bertujuan untuk mengetahui pengaruh kombinasi enhancer tween 80 dan etanol terhadap pelepasan dan penetrasi zat aktif ibuprofen dalam sediaan gel, pengaruhnya terhadap mutu fisik sediaan serta formula optimum dari kombinasi keduanya. Penelitian ini menggunakan metode simplex lattice design dengan 2 faktor yaitu tween 80 dan etanol pada sediaan gel formula 1 ; formula 2; dan formula 3 secara berurutan 100\%:0\%; 50\%:50\%; 0\%:100\%. Dispersi padat ibuprofen-PEG 6000 dibuat dengan metode peleburan, kemudian dilakukan uji FTIR lalu dibuat sediaan gel. Uji penetrasi zat dilakukan dengan menggunakan alat sel difusi franz dengan membran selofan kemudian dilakukan penentuan formula optimum berdasarkan counterplot yang diperoleh dari optimasi menggunakan Design Expert 10.0.1 trial version dengan parameter titik kritis viskositas dan penetrasi zat. Hasil penelitian menunjukkan bahwa kombinasi tween 80 dan etanol dapat mempengaruhi viskositas dan penetrasi zat, tween 80 memiliki pengaruh yang lebih besar daripada etanol. Konsentrasi tween $804.681 \%$ dan etanol $16.319 \%$ menghasilkan formula optimum dengan viskositas, daya lekat, dan penetrasi obat paling optimum.
\end{abstract}

Kata kunci: Ibuprofen, gel, dispersi padat, optimasi, simplex lattice design

\begin{abstract}
Ibuprofen is a part of Non Steroid Anti-Inflamatory Drug (NSAID) that used as treatment of pain or inflammatory. Solid dispersion method may improve the solubility of ibuprofen. Ibuprofen was made into a gel product to overcome the side effect. Addition of an enhancer in a gel may increase the penetration of an active substance. The purpose of this study is to understand the effect of tween 80 and ethanol as an enhancer to penetration and drug release of ibuprofen in gel, the effect to physical quality of gel, and to obtain the optimum formula of the combination of enhancer. This study used simplex lattice design with two factor which is tween 80 and ethanol in gel product formula 1; formula 2; and formula 3 in sequence 100\%:0\%; 50\%:50\%; 0\%:100\%. Solid dispersion of ibuprofen-PEG 6000 was made with melting method and tested with FTIR before made into gel product. Penetration test is done by using Franz diffusion cell with selofan membrane and the determination of the
\end{abstract}


optimum formula obtained based on counterplot from optimization with design expert 10.0.01 trial version with the parameters of the critical level is viscosity and penetration substanced. The results showed the combination of tween 80 and ethanol could affect viscosity and penetration of active substance, tween 80 had a greater effect than ethanol. The proportion of tween $804.681 \%$ and ethanol $16.319 \%$ produces the optimum formula with the most optimum viscosity, adhesion, and drug penetration

Key word: Ibuprofen, gel, solid dispersion, optimization, simplex lattice design

\section{Pendahuluan}

Ibuprofen merupakan golongan non steroid anti-inflamatory drug (NSAID) tidak selektif turunan asam propionat, yang sering digunakan dalam pengobatan nyeri akut dan inflamasi seperti artritis reumatoid dan osteoartritis (Bushra dan Aslam 2010). Penggunaan NSAID oral seperti ibuprofen dapat menyebabkan efek samping antara lain kerusakan lambung, ginjal serta pendarahan (Vinklarkova 2015), sehingga alternatif untuk mengurangi efek samping yang ditimbulkan adalah dengan mengubah rute administrasi obat melalui rute transdermal.

Ibuprofen adalah golongan obat Biopharmaceutics Classification System (BCS) kelas II, dimana golongan obat tersebut memiliki kelarutan yang rendah da permeabilitas yang tinggi. Kelarutan ibuprofen dapat ditingkatkan salah satunya dengan menggunakan metode dispersi padat. Peningkatan kelarutan ibuprofen bertujuan untuk meningkatkan ketersediaan hayati melalui peningkatan absorbsi obat ke dalam tubuh. Kelarutan ibuprofen dapat ditingkatkan dengan membuat dispersi padat Ibuprofen-PEG 6000 dengan perbandingan 1:1.5 menggunakan metode peleburan (Zaini et al. 2010).

Rute transdermal merupakan salah satu sistem penghantaran obat yang dapat mentransfer obat ke dalam sirkulasi sistemik melalui kulit. Keuntungan rute transdermal yaitu obat tidak kontak secara langsung dengan mukosa lambung dan dapat menghindari first pass metabolism di hati (Saroha et al. 2010), meningkatkan kepatuhan dan mengurangi biaya pengobatan, meningkatkan bioavailabilitas, rute terbaik untuk pasien pediatri, rute yang cocok untuk pasien yang tidak biasa atau muntah, kemungkinan overdosis lebih kecil dan mudah mendeteksi obat (Durand et al 2012). Gel merupakan salah satu sediaan topikal atau transdermal yang sudah banyak digunakan.
Kandungan komponen air yang tinggi juga menyebabkan gel memiliki kemampuan menghidrasi stratum korneum sehingga penetrasi perkutan obat menembus kulit menjadi lebih mudah dibandingkan dengan salep dan krim (Rawat 2011).

Peningkat penetrasi didefinisikan sebagai zat yang mampu meningkatkan penetrasi obat-obatan ke dalam kulit dan sistem penghantaran obat transdermal merupakan cara yang lebih efektif pemberian obat melalui kulit (Patil et al. 2014). Tween 80 dan Etanol termasuk dalam golongan peningkat penetrasi kimia. Peningkat penetrasi kimia membantu penetrasi obat melalui lapisan kulit stratum korneum, berinteraksi dengan protein interselular atau memperbaiki partisi obat ke dalam stratum korneum (Garg et al. 2013). Tween 80 merupakan surfaktan non-ionik yang dapat berperan sebagai enhancer serta tidak menimbulkan iritasi. Etanol tergolong dalam alkohol yang dapat berfungsi sebagai pembawa, pelarut, dan bahkan peningkat penetrasi bahan obat ke dalam kulit (stratum korneum) pada sistem penghantaran transdermal. Etanol dapat meningkatkan absorbsi perkutan dengan cara berinteraksi dan modulasi lipid pada stratum korneum, serta melarutkan lipid pada konsentrasi tinggi (Heard 2015).

\section{Metode Penelitian}

Penelitian ini bersifat ekperimental laboratorik. Tahapan yang dilakukan pada penelitian adalah pembuatan dispersi padat ibuprofen-PEG 6000 (1:1.5), pengujian FT-IR dispersi padat, penetapan kadar (\%recovery) ibuprofen, pembuatan gel, pengujian sifat fisik gel, dan uji penetrasi iburprofen.

\section{Alat}

Alat yang digunakan dalam penelitian ini adalah spektrofotometer UV-Vis Shimadzu 1800 (Tokyo, Jepang), spektroskopi FT-IR 
IRPrestige-21, Honson Horizontal Diffusion Cell System Digital (IKA, Jerman), magnetic stirrer, water bath, timbangan digital, cawan porselin, beaker glass, seperangkat alat uji homogenitas, daya sebar, daya lekat, viskometer strormer, $\mathrm{pH}$ meter, mortir dan stamfer.

\section{Bahan}

Bahan yang digunakan dalam penelitian ini adalah ibuprofen BP dari IOL Chemicals and Pharmaceuticals, ltd., karbopol (karbomer 940), tween 80, etanol 95\%, PEG 6000, TEA, KBr, dapar fosfat $\mathrm{pH} 7.4$ berasal dari laboratorium teknologi farmasi Universitas Setia Budi, membran selofan diameter $27 \mathrm{~mm}$.

\section{Tahapan Penelitian}

\section{Pembuatan Dispersi padat}

Pembuatan dispersi padat dilakukan dengan perbandingan ibuprofen-PEG 6000 1: 1,5. Bahan ibuprofen dan PEG 6000 ditimbang sesuai dengan formulasi, dileburkan pada suhu $80^{\circ} \mathrm{C}$ di atas water bath. PEG dimasukan ke dalam cawan yang diletakkan di atas water bath sampai melebur sempurna, lalu ditambahkan ibuprofen sedikit demi sedikit dan lalu diaduk sampai homogen. Leburan didinginkan pada ice bath lalu disimpan dalam desikator selama 24-48 jam sampai kering sebelum dihaluskan menggunakan mortir dan stamfer, kemudian diayak menggunakan ayakan no.80.

\section{Uji FTIR}

Pemeriksaan ibuprofen yang terdispersi dalam pembawa PEG 6000 dilakukan dengan menggunakan instrumen spektroskopi FT-IR. Dispersi padat Ibuprofen-PEG 6000 dicampurkan dengan KBr. Perbandingan yang digunakan sebesar $3 \mathrm{mg}$ dispersi padat Ibuprofen-PEG 6000 dengan $300 \mathrm{mg} \mathrm{KBr}$, kemudian hasil campuran dimasukkan ke dalam alat pompa hidrolik. Tekan dengan tekanan 6 ton sehingga terbentuk pellet. Analisis pellet dilakukan menggunakan alat spektroskopi FTIR. Hasil dibandingkan dengan spektrum ibuprofen murni dan PEG 600 murni.

\section{Penentuan \% Recovery Ibuprofen}

Dosis ibuprofen dalam sediaan topikal yaitu $1 \%$ sehingga perlu dilakukan penetapan kadar dispersi padat setara 1\% ibuprofen. Penetapan kadar ibuprofen dalam dispersi padat ibuprofen-PEG 6000 ditentukan menggunakan metode spektrofotometri UV-Vis. Ditimbang dispersi padat ibuprofen dan dilarutkan dengan $\mathrm{NaOH}$. Larutan dispersi padat Ibuprofen-PEG 6000 yang sudah diencerkan diamati serapannya dengan spektrofotometri UV-Vis pada panjang gelombang maksimum yang terpilih. Kadar yang diperoleh lalu dibandingkan dengan kadar hasil teoritis untuk megetahui \% recovery Ibuprofen dalam dispersi padat Ibuprofen-PEG 6000. Replikasi dilakukan sebanyak 3 kali kemudian dihitung koefisien variasi (CV) dari hasil tersebut.

\section{Pembuatan Gel}

Pembuatan gel dispersi padat ibuprofen-PEG 6000 dilakukan dengan cara mendispersikan basis karbopol ke dalam akuades dan diberi TEA hingga terbentuk basis gel. Dispersi padat dilarutkan dalam etanol kemudian ditambahkan tween 80 dan diaduk hingga homogen, kemudian ditambahkan ke dalam basis gel sedikit demi sedikit dan diaduk hingga homogen.

Tabel 1. Formula Gel Dispersi Padat Ibuprofen-PEG 6000

\begin{tabular}{|c|c|c|c|c|}
\hline Bahan & Fungsi & $\begin{array}{c}\text { Formula } \\
1(\%)\end{array}$ & $\begin{array}{c}\text { Formula } \\
2(\%)\end{array}$ & $\begin{array}{c}\text { Formula } \\
3(\%)\end{array}$ \\
\hline $\begin{array}{l}\text { Dispersi } \\
\text { padat } \\
\text { Ibuprofen- } \\
\text { PEG } 6000\end{array}$ & $\begin{array}{c}\text { Bahan } \\
\text { aktif }\end{array}$ & $2.75^{*}$ & $2.75^{*}$ & $2.75^{*}$ \\
\hline Karbo pol & $\begin{array}{c}\text { Gelling } \\
\text { agent }\end{array}$ & 1 & 1 & 1 \\
\hline Tween 80 & $\begin{array}{c}\text { Penetration } \\
\text { enbancer }\end{array}$ & 1 & 3.5 & 6 \\
\hline Etanol & $\begin{array}{c}\text { Penetration } \\
\text { enbancer }\end{array}$ & 20 & 17.5 & 15 \\
\hline TEA & $\begin{array}{c}\text { Alkealizing } \\
\text { agent }\end{array}$ & 2 & 2 & 2 \\
\hline $\begin{array}{c}\text { Aquades } \\
\text { ad }\end{array}$ & & 100 & 100 & 100 \\
\hline
\end{tabular}

Dispersi padat ibuprofen-PEG 6000 setara dengan $1 \%$ ibuprofen.

\section{Evaluasi Sediaan Gel}

Evaluasi sediaan gel meliputi pengamatan organoleptis, homogenitas, pengujian $\mathrm{pH}$, pengujian viskositas, pengujian daya sebar, pengujian daya lekat dan pengujian penetrasi.

Pengujian organoleptis gel dilakukan dengan pengamatan visual gel berupa warna, bau, dan konsistesi sediaan gel dispersi padat ibuprofen (Handayani 2012). 
Pengujian homogenitas dilakukan dengan mengoleskan gel pada plat kaca transparan, kemudian diamati, diraba dan jika tidak ada butiran kasar maka sediaan uji dinyatakan homogen (Nikam 2017).

Pengujian $\mathrm{pH}$ dilakukan menggunakan $\mathrm{pH}$ meter digital. Persyaratan $\mathrm{pH}$ sediaan gel yang dapat ditoleransi untuk tidak mengiritasi kulit yaitu 4.5-6.5 (Naibaho 2013).

Viskositas sediaan gel diuji menggunakan alat viskometer stormer pada suhu ruang. Nilai viskositas (dPa's) dapat dibaca dari skala rotor dengan viskositas gel yang baik yaitu antara 50-1000 dPa's, dengan optimalnya 200 dPa's (Nurahmanto 2017).

Pengujian daya sebar sebanyak 0.5 gram sampel diletakkan pada pusat antara dua lempeng gelas kaca berskala dan diletakkan beban dengan berat $50 \mathrm{~g}$ dengan interval 1 menit lalu diukur diameter dari 4 sisi, kemudian berat ditambah menjadi $100 \mathrm{~g}$ dan $150 \mathrm{~g}$ masingmasing dengan interval yang sama. Persyaratan daya sebar yang baik yaitu 3-7 cm (Nurahmanto 2017).

Pengujian daya lekat sebanyak 0.5 gram sediaan di atas gelas obyek, kemudian diletakkan gelas obyek yang lain pada bagian atas sediaan tersebut, kemudian ditekan dengan beban $1 \mathrm{~kg}$ selama 5 menit. Gelas obyek tersebut dipasang alat uji kemudian diberi beban seberat 80 gram dan dicatat waktu hingga kedua gelas obyek terpisah (Azkiya et al. 2017). Persyaratan uji daya lekat yaitu waktu daya lekat lebih dari 1 detik (Yusuf et al. 2017).

\section{Uji Penetasi Sediaan Gel}

Pengujian penetrasi obat in vitro gel dilakukan dengan cara pada kompartemen reseptor diisi dengan dapar fosfat $\mathrm{pH} 7,4$ dan dijaga suhu $37 \pm 0.5^{\circ} \mathrm{C}$, serta diaduk menggunakan magnetic stirrer $100 \mathrm{rpm}$ selama 1.5 jam. Membran selofan diletakkan di antara kompartemen donor dan kompartemen reseptor. Formula gel dispersi padat ibuprofenPEG 6000 sejumlah 2 g diaplikasikan pada permukaan membran. Pengambilan larutan sampel sebanyak $5 \mathrm{~mL}$ pada menit ke-5, 10, 15, 30, 45, 60, dan 90 dari kompartemen reseptor menggunakan pipet mikro dan segera

Berdasarkan hasil dari pemeriksaan gugus fungsi FT-IR, sepektrum dispersi padat menunjukkan munculnya pita-pita absorpsi utama gugus fungsi yang terdapat pada digantikan dengan dapar fosfat $\mathrm{pH} 7.4$ sejumlah voume yang sama. Larutan sampel selanjutnya dibaca serapan menggunakan spektofotometri UV-Vis pada panjang gelombang maksimum menggunakan blanko dapar fosfat $\mathrm{pH}$ 7.4. Berdasarkan data serapan yang diperoleh, kemudian dilakukan perhitungan jumlah kumulatif ibuprofen yang tertranspor melewati membran selofan (Nurahmanto 2017).

\section{Penentuan Formula Optimum}

Penentuan formula optimum gel dispersi pada ibuprofen-PEG 6000 dengan menggunakan parameter daya lekat, viskositas, dan laju penetrasi zat dengan melihat nilai fluks masing-masing diberi kriteria yang sesuai dengan besarnya pengaruh terhadap gel menggunakan persamaan simplex lattice design $(\mathrm{Y}=\mathrm{B} 1(\mathrm{~A})+\mathrm{B} 2+\mathrm{B} 12(\mathrm{~A})(\mathrm{B}))$. Penentuan formula optimum dengan menggabungkan counter plot pada masing-masing parameter menggunakan program Design Expert $\mathbb{R}$ 10.0.1 trial version.

\section{Hasil Dan Pembahasan Dispersi Padat Ibuprofen-PEG 6000}

Hasil dispersi padat ibuprofen dengan pembawa PEG 6000 dari lelehan campuran yang sudah didinginkan, digerus, dan diayak berupa serbuk putih halus dan tidak berbau. Dispersi padat ibuprofen mengalami peningkatan kelarutan sebesar 1.3 kali dibandingkan dengan ibuprofen murni yaitu dengan kelarutan dispersi padat dalam air sebesar $28.6 \mathrm{mg} / \mathrm{L}$ dan kelarutan ibuprofen sebesar $21 \mathrm{mg} / \mathrm{L}$.

\section{Pemeriksaan Dispersi Padat Ibuprofen dengan FTIR}

Tabel 2. Hasil Pemeriksaan FT-IR

\begin{tabular}{cccc}
\hline $\begin{array}{c}\text { Gugus } \\
\text { fungsi }\end{array}$ & $\begin{array}{c}\text { Ibuprofen } \\
\left(\mathbf{( m m}^{-1}\right)\end{array}$ & $\begin{array}{c}\text { PEG } \\
\mathbf{6 0 0 0} \\
\left(\mathbf{c m}^{-1}\right)\end{array}$ & $\begin{array}{c}\text { Dispersi } \\
\text { ibuprofen } \\
\left(\mathbf{c m}^{-1}\right)\end{array}$ \\
\hline C-H & 2954.95 & 2883.58 & 2954.95 \\
stretching & & 2875.86 \\
COOH & 1720.50 & & 1720.50 \\
C=C & 1462.04 & & 1465.90 \\
aromatis & & 1145.72 & 1147.65 \\
C-O & & 1109.07 & 1112.93 \\
stretching & & & \\
\hline
\end{tabular}

spektrum ibuprofen dan PEG 6000 yaitu pada $\mathrm{C}-\mathrm{H}$ stretching 2953.92 dan $2875.86 ; \mathrm{C}=\mathrm{O}$ karboksilat $1720.50 ; \mathrm{C}=\mathrm{C}$ aromatis 1465.90 ; CO stretching 1147.65 ; 1114.86 ; O-H 3278.99- 
3379.29. Pita-pita absorpsi yang utama pada ibuprofen dan PEG 6000 tetap muncul tetapi terdapat pergeseran bilangan gelombang yang tidak jauh berbeda, hal ini menunjukkan tidak terjadi interaksi kimia antara PEG 6000 dan ibuprofen (Zaini et al. 2010).

Pembawa PEG 6000 dari dispersi padat memiliki kelarutan dalam air yang tinggi karena memiliki gugus hidroksil (OH), sehingga ibuprofen yang terdispersi di dalam PEG 6000 kelarutannya akan meningkat yang ditunjukan adanya ikatan hidrogen pada gugus hidroksil $(\mathrm{OH})$ pada spektrum dispersi padat dengan bilangan gelombang 3278.99 - 3379.29, adanya ikatan hidrogen pada dispersi padat juga akan membantu melonggarkan ikatan antar molekul ibuprofen sehingga obat akan berada dalam bentuk yang lebih amorf, ikatan hidrogen telah dibuktikan menjadi faktor penting dalam peningkatan stabilitas obat dalam bentuk amorf (Tran 2020). Ibuprofen yang berikatan dengan pembawa PEG 6000 akan memiliki kelarutan yang lebih tinggi dibandingkan dengan kelarutan ibuprofen murni.

\section{Penetapan Kadar Dispersi Padat}

Sampel dispersi padat ibuprofen-PEG

6000 dibaca dengan menggunakan spektrofotometri UV-Vis pada panjang gelombang $264 \mathrm{~nm}$ dilakukan sebanyak 3 replikasi. Hasil absorbansi kemudian dimasukkan kedalam kurva kalibrasi untunk mengetahui kadar ibuprofen murni dengan menghitung nilai $\mathrm{CV}$. Hasil rata-rata \%recovery ibuprofen dengan pembawa PEG 6000 sebesar $90.77 \% \pm 1.396$. Hasil \% recovery dapat dilihat pada tabel 3 .

\section{Hasil Pengujian Mutu Fisik Gel Ibuprofen}

Uji mutu fisik gel ibuprofen melibuti pengujian organoleptis gel, homogenitas, $\mathrm{pH}$, daya sebar, dan daya lekat. Hasil dapat dilihat pada tabel 4.

Pengujian organoleptis ini bertujuan untuk memeriksa apakah sediaan gel dari F1, F2, dan F3 sudah memenuhi spesifikasi gel yang diinginkan. Berdasarkan hasil pengamatan organoleptis diketahui sediaan gel ibuprofen berbentuk gel, berbau etanol dan tween 80 yang khas, serta berwarna putih jernih dan tidak keruh. Gel berwarna putih dikarenakan dispersi padat ibuprofen-PEG 6000 yang berwarna putih terdispersi di dalam basis karbopol dan tidak larut sempurna, penggantian karbopol dengan basis gel lain kemungkinan dapat menghasilkan sediaan gel yang lebih jernih.

Tabel 3. Hasil \% Recovery Dispersi Padat Ibuprofen

\begin{tabular}{ccccccc}
\hline Replikasi & Absorbansi & $\begin{array}{c}\text { Kadar } \\
\text { ibuprofen } \\
\text { penelitian } \\
(\mathrm{ppm})\end{array}$ & $\begin{array}{c}\text { Kadar } \\
\text { ibuprofen } \\
\text { teoritis (ppm) }\end{array}$ & \% Recovery & $\begin{array}{c}\text { Kadar } \\
\text { rata-rata } \\
\pm \mathrm{SD}\end{array}$ & $\mathrm{CV}$ \\
\hline 1 & 0.231 & 109.50 & 120.4 & 90.98 & $90.77 \pm$ & $1.53 \%$ \\
2 & 0.226 & 106.78 & 119.6 & 89.28 & 1.396 & \\
\hline
\end{tabular}

Tabel 4. Hasil Uji Mutu Fisik Gel Ibuprofen

\begin{tabular}{ccccc}
\hline \multicolumn{2}{c}{ Parameter } & \multicolumn{3}{c}{ Formula } \\
& Bentuk & I & II & III \\
\hline \multirow{2}{*}{ Warna } & Gel & Gel & Gel \\
Organoleptis & Puth jernih & Putih jernih & Putih jernih \\
& Bau & Etanol dan khas & Etanol dan khas & Etanol dan khas \\
& tween 80 & tween 80 & tween 80 \\
Homogenitas & Homogen & Homogen & Homogen \\
pH & 4.83 & 5.82 & 5.90 \\
Viskositas (dPa's) & $90.67 \pm 1.15$ & $140.33 \pm 0.58$ & $150 \pm 1.00$ \\
Daya sebar 150g (cm) & 4.74 & 3.61 & 3.48 \\
Daya lekat (detik) & 0.25 & 1.14 & 1.74 \\
\hline
\end{tabular}


Pengujian homogenitas dilakukan untuk mengetahui apakah zat aktif ibuprofen dalam sediaan sudah terdistribusi merata atau tidak. Hasil uji homogenitas gel menunjukan ketiga formula sudah homogen yang ditandai dengan tidak adanya partikel kasar atau bahan padat yang dapat diraba saat dioleskan pada plat kaca, sehingga dapat diasumsikan bahwa ibuprofen sudah terdistribusi secara merata pada sediaan gel.

Tujuan pengujian $\mathrm{pH}$ yaitu untuk mengetahui jika sediaan gel aplikasikan ke kulit akan menimbulkan iritasi atau tidak. Berdasarkan hasil pengamatan diketahui bahwa setiap formula memiliki $\mathrm{pH}$ yang berbeda pada masing-masing sediaan gel. Ketiga formula sediaan gel sudah memenuhi kriteria $\mathrm{pH}$ sediaan yang tidak mengiritasi kulit yaitu 4.5-6.5 (Naibaho 2013).

Tujuan uji viskositas untuk mengetahui tingkat kekentalan dari sediaan gel. Nilai viskositas dari sediaan sendiri akan berpengaruh terhadap daya lekat dan daya sebar sediaan, diamana semakin tinggi viskositasnya maka daya lekat akan semakin tinggi dan daya sebarnya akan semakin rendah dan sebaliknya. Berdasarkan hasil pengujian diketahui bahwa viskositas $\mathrm{F} 1<\mathrm{F} 2<\mathrm{F} 3$. Viskositas terbesar terdapat pada F3 karena adanya kandungan tween 80 dengan konsentrasi terbesar. Perbedaan nilai viskositas dapat juga disebabkan oleh viskositas masing-masing bahan yaitu tween 80 dan etanol. Tween 80 memiliki visokistas $425 \mathrm{mPa}$ 's dan viskositas etanol adalah $1.22 \mathrm{mPa}$ 's (Rowe et al. 2009). Viskositas sediaan memenuhi syarat viskositas sediaan gel yang baik yaitu antara 50-1000 dPa's, dengan optimalnya $200 \mathrm{dPa}$ 's (Nurahmanto 2017).

Daya sebar suatu sediaan gel menunjukkan kemampuan sediaan untuk terdistribusi secara merata. Hasil dari uji daya sebar menunjukkan bahwa ketiga formula sediaan memiliki daya sebar sesuai dengan syarat diameter penyebaran gel menurut literatur yaitu sekitar 3-7 cm (Nurahmanto 2017).

Waktu daya lekat sediaan gel sangat mempengaruhi absorbsi obat karena obat dapat terabsorbsi jika terjadi kontak antara sediaan dan kulit. Berdasarkan hasil uji daya lekat diketahui daya lekat F3>F2 $>$ F1, daya lekat F1 $<1$ detik dan tidak memenuhi persyaratan, hal ini dapat dipengaruhi oleh viskositas gel dimana semakin tinggi viskositas maka gel akan semakin tertahan dan sulit untuk mengalir (Shan dan Imam 2018).

\section{Pengujian Laju Penetrasi}

Uji penetrasi dilakukan dengan menggunakan sel difusi Franz horizontal. Uji penetrasi dengan sel difusi franz bertujuan untuk mengetahui adanya pengaruh kombinasi senyawa peningkat penetrasi tween 80 dan etanol terhadap penetrasi obat melalui membran. Jumlah kumulatif ibuprofen yang terpenetrasi dari sediaan gel dispersi padat dapat dilihat pada gambar 1.

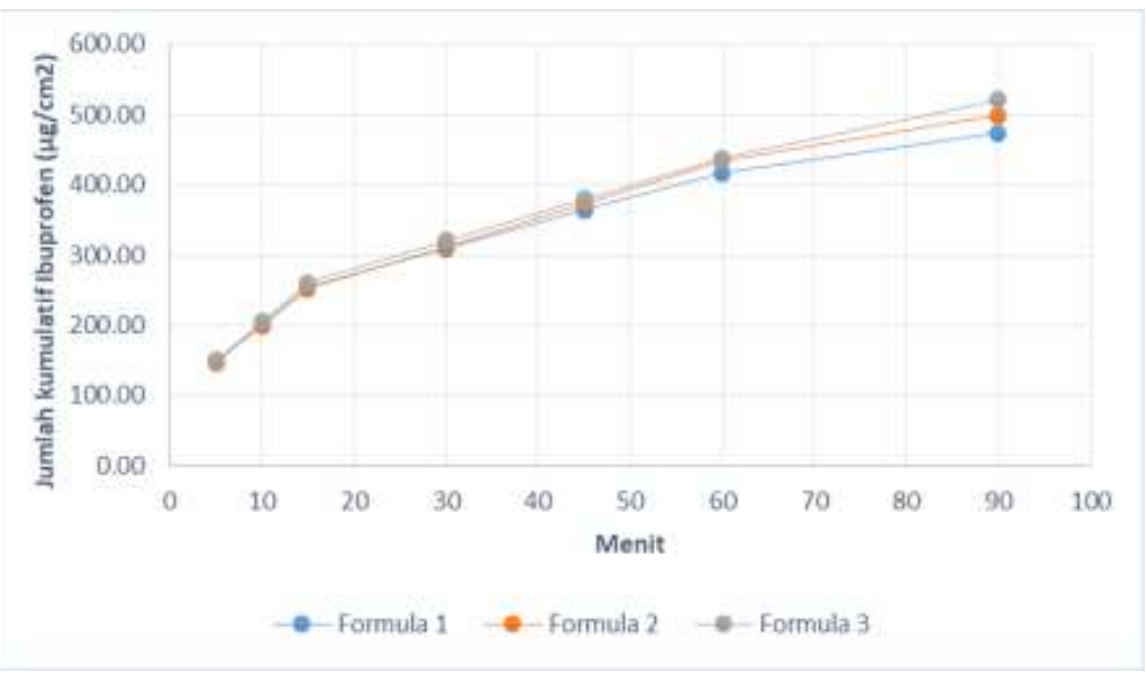

Gambar 1. Profil Jumlah Kumulatif Ibuprofen Yang Terpenetrasi

Keterangan:

Formula 1: Kombinasi tween 80 1\% dan etanol 20\%, viskositas gel $90.67 \pm 1.15 \mathrm{dPa}$ 's

Formula 2: Kombinasi tween $803.5 \%$ dan etanol 17.5\%, viskositas gel $140.33 \pm 0.58$ dPa's

Formula 3: Kombinasi tween 80 6\% dan etanol 15\%, viskositas gel 1 
Berdasarkan profil tersebut dapat diketahui dengan bertambahnya waktu maka jumlah ibuprofen yang terpenetrasi juga akan semakin meningkat. Jumlah kumulatif ibuprofen yang terpenetrasi pada menit ke- 90 pada masing-masing sediaan gel F1, F2, dan F3 berturut-turut adalah $474.25 \mu \mathrm{g} / \mathrm{cm} 2 ; 499.21$ $\mu \mathrm{g} / \mathrm{cm}^{2}$; dan $521.11 \mu \mathrm{g} / \mathrm{cm}^{2}$. Jumlah kumulatif ibuprofen yang terpenetrasi menunjukkan bahwa tween 80 lebih besar pengaruhnya terhadap peningkatan penetrasi ibuprofen, dimana jumlah kumulatif ibuprofen yang terpenetrasi semakin tinggi dengan bertambahnya konsentrasi tween 80 (Pandey et al. 2014).

Etanol pada formula dapat meningkatkan konsentrasi misel kritis dari tween 80 sehingga menghasilkan efek sinergis dalam peningkatan penetrasi ibuprofen (Pandey et al. 2014). Efek peningkatan penetrasi etanol yang signifikan yaitu pada konsentrasi 30\% dan di bawah itu tidak terlalu signifikan (Gupta et al. 2020). Oleh karena itu, dengan peningkatan konsentrasi tween 80 di dalam formula juga meningkatkan penetrasi ibuprofen.

\section{Penentuan Formula Optimum}

Penentuan formula optimum dilakukan dengan aplikasi Design Expert 10.0.1 trial version

secara Simplex Lattice Design. Optimasi yang dilakukan pada penelitian ini yaitu terhadap komposisi tween 80 dan etanol pada sediaan gel dispersi padat ibuptofen dengan parameter yang digunakan berdasarkan respon daya lekat, viskositas, dan fluks penetrasi ibuprofen.

Hasil analisis respon daya lekat ketiga formula secara simplex lattice design diperoleh persamaan sebagai berikut:

Daya lekat $=1.74(\mathrm{~A})+0.25(\mathrm{~B})+$ $0.59(\mathrm{~A})(\mathrm{B}) . .(1)$

Keterangan:
(A) : Konsentrasi Tween 80
(B) : Kosentrasi Etanol

Berdasarkan persamaan di atas diketahui bahwa penambahan konsentrasi tween 80 (koefisien 1.74) akan meningkatkan daya lekat begitu pula dengan etanol (koefisien 0.25 ) serta kombinasi keduanya dapat meningkatkan daya lekat sediaan gel dispersi padat ibuprofen (koefisien 0.59). Peningkatan daya lekat akan lebih besar bila konsentrasi penambahan tween 80 lebih banyak dibandingkan dengan etanol, hal ini dikarenakan tween 80 memiliki viskositas yang lebih tinggi sehingga dapat menahan sediaan di permukaan membran.

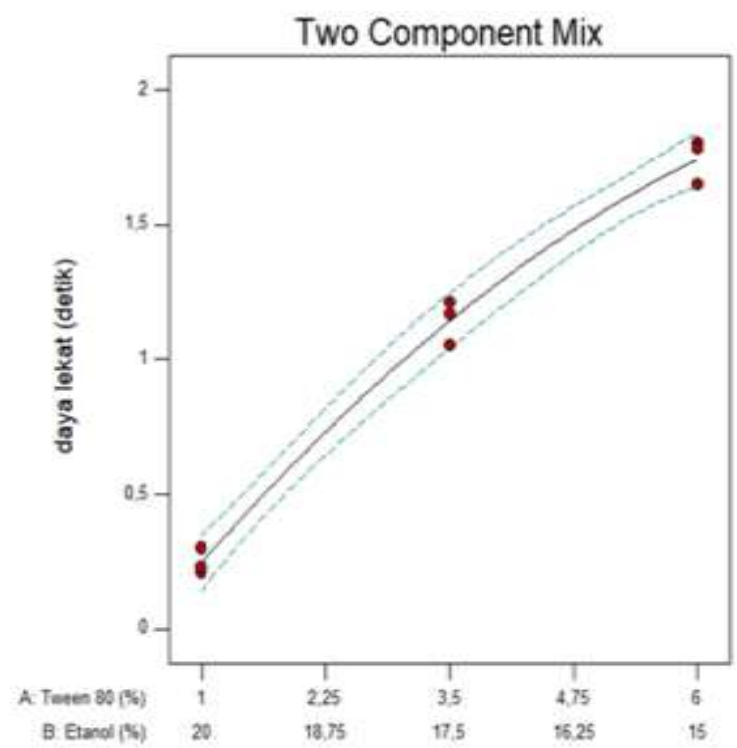

Gambar 2. Kurva daya lekat berdasarkan simplex lattice design

Hasil analisis respon viskositas ketiga formula secara simplex lattice design diperoleh persamaan sebagai berikut:

Viskositas $=150(\mathrm{~A})+90.67(\mathrm{~B})+80(\mathrm{~A})(\mathrm{B}) \ldots .(2)$
Keterangan:

(A) : Konsentrasi Tween 80

(B) : Kosentrasi Etanol 

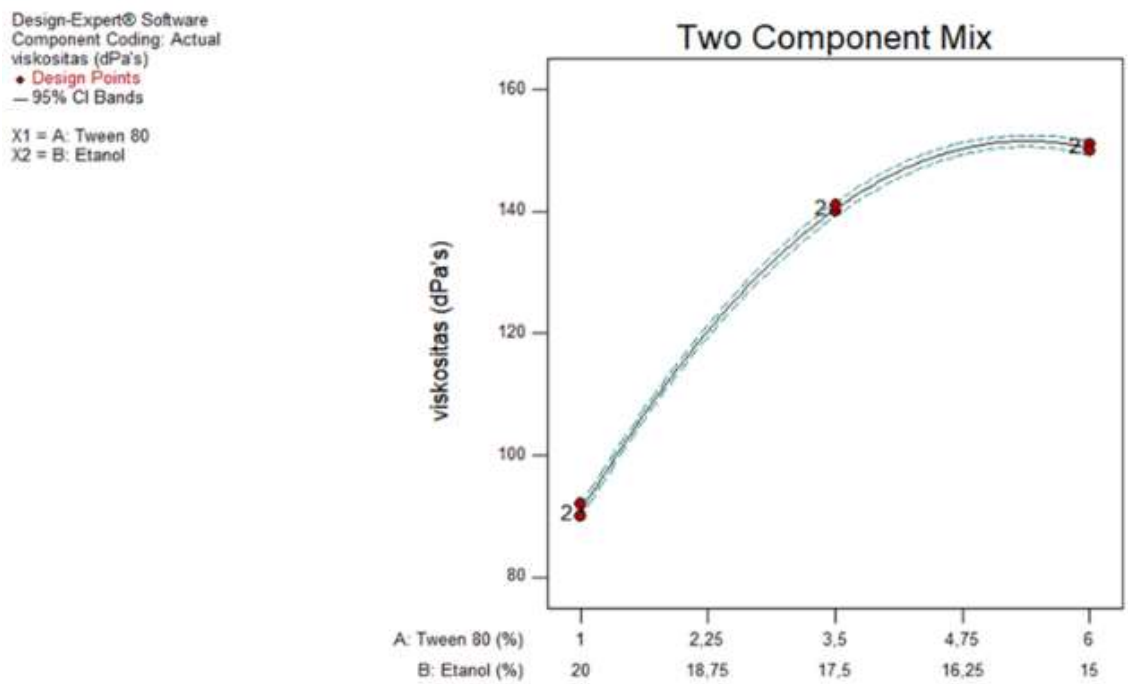

Gambar 3. Kurva viskositas berdasarkan simplex lattice design

Persamaan tersebut menunjukkan bahwa tween 80 (koefisien 150) memiliki pengaruh lebih besar terhadap peningkatan viskositas sediaan dibandingkan dengan etanol (koefisien 90.67) serta kombinasi keduanya juga berpengaruh terhadap peningkatan viskositas sediaan (koefisien 80) yang berarti kombinasi tween 80 dan etanol akan menaikan viskositas.

Nilai fluks penetrasi diperoleh dari perhitungan slope anatara jumlah kumulatif ibuprofen yang tertranspor dan waktu (menit) pengujian. Dari analisis hasil respon nilai fluks penetrasi secara simplex lattice design diperoleh sebuah persamaan sebagai berikut:
Fluks $=4.17(\mathrm{~A})+3.67(\mathrm{~B})+0.35(\mathrm{~A})(\mathrm{B})$

Keterangan:
(A) : Konsentrasi Tween 80
(B) : Kosentrasi Etanol

Berdasarkan persamaan tersebut diketahui bahwa tween 80 (koefisien 4.17) mempunyai pengaruh yang lebih besar daripada etanol (koefisien 3.67) terhadap besarnya nilai fluks penetrasi. Tween 80 dan etanol (koefisien 0.35) pada persamaan menunjukkan bahwa ada hubungan antar tween 80 dan etanol terhadap besarnya nilai fluks penetrasi sehingga kombinasi keduannya dapat meningkatkan penetrasi ibuprofen dalam sediaan gel.
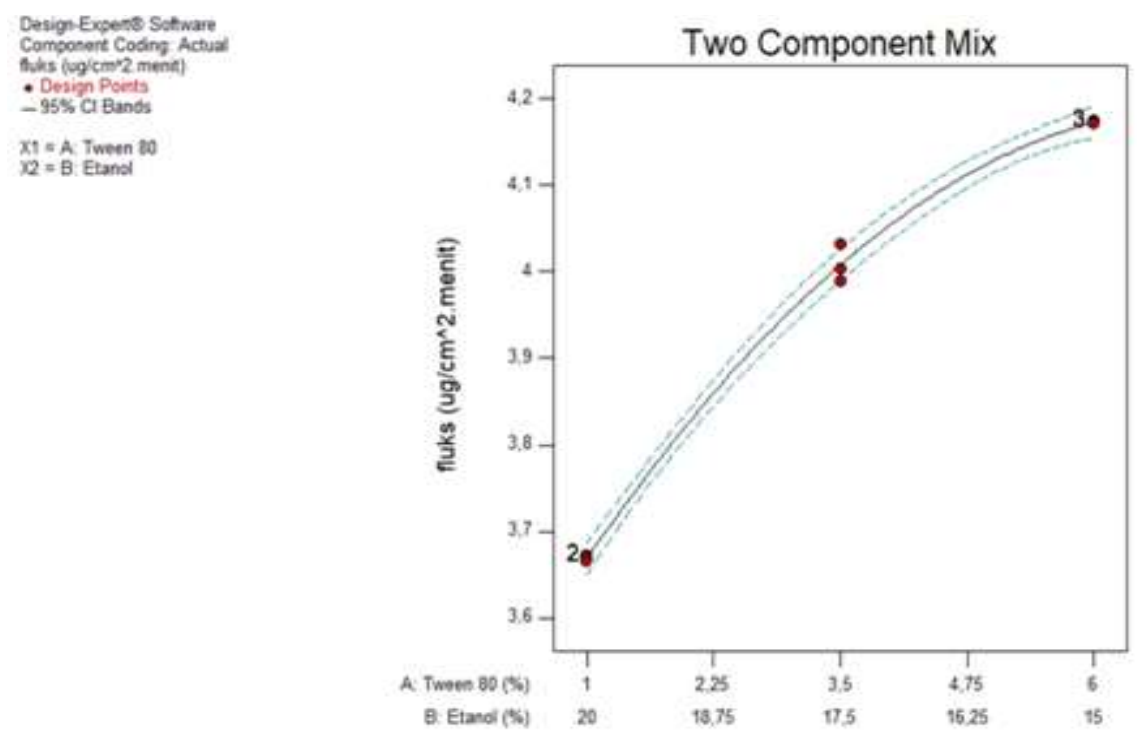

Gambar 4. Kurva fuks penetrasi berdasarkan simplex lattice design 


\section{Optimasi Formula}

Optimasi formula dilakukan dengan terlebih dahulu menetapkan parameter titik kritis untuk menentukan kriteria sediaan yang diinginkan.

Tabel 5. Kriteria formula optimum

\begin{tabular}{ccccc}
\hline \multirow{2}{*}{ Parameter } & \multirow{2}{*}{ Target } & \multirow{2}{*}{ Importance } & \multicolumn{2}{c}{ Limits } \\
\cline { 4 - 5 } & & & Lower & Upper \\
\hline Viskositas & In target & ++ & 90 & 150 \\
& & & $\mathrm{dPa}$ 's & $\mathrm{dPa}$ 's \\
Daya lekat & Maximize & ++ & 0.21 & 1.8 \\
& & & detik & detik \\
Fluks & Maximize & +++ & 3.66505 & 4.17385 \\
Penetrasi & & & & \\
\hline
\end{tabular}

Parameter yang digunakan sebagai titik kritis yaitu, daya lekat, visoksitas, dan fluks penetrasi ditentukan kriteria yang diinginkan pada formula optimum kemudian dimasukkan ke dalam program Design Expert ${ }^{\circledR}$ 10.0.1 trial. Kriteria optimasi seperti pada tabel 5.

Berdasarkan kriteria di atas, viskositas diberi nilai importance plus 2 dengan target 150
dPa's, untuk daya lekat kriteria yang digunakan adalah semaksimal mungkin dan diberi nilai importance plus 2 karena berhubungan dengan waktu kontak sediaan pada kulit, serta kriteria untuk fluks penetrasi yaitu dengan target semaksimal mungkin dengan nilai importance plus 4 karena formula optimum yang diperoleh diharapkan dapat memberikan fluks penetrasi yang paling optimum. Dari kriteria parameter optimasi yang sudah ditetapkan kemudian menghasilkan sebuah formula optimum dengan nilai desirability sebesar 0.878 . Nilai maksimum desirability adalah 1 yang menunjukkan kemampuan program untuk menghasilkan formula optimum yang memenuhi kriteria yang ditetapkan, nilai desirability yang semakin mendekati 1 menunjukkan bahwa formula optimum yang diperoleh semakin dekat dengan kriteria yang diinginkan.

\section{Solutions}

$\begin{array}{rrrrrrrr}\text { Number } & \text { Tween } 80 & \text { Etanol daya lekat } & \text { viskositas } & \text { fluks } & \text { Desirability } & \\ 1 & \underline{4,681} & \underline{16,319} & \underline{1.464} & \underline{150,000} & \underline{4.107} & \underline{0.878} & \underline{\text { Selected }}\end{array}$

Gambar 5. Formula optimum berdasarkan simplex lattice design

\section{Verifikasi Formula Optimum}

Verifikasi formula optimum dilakukan dengan uji one sample t-test. Formula optimum dapat dikatakan terverifikasi apabila hasil uji parameter kritis penelitian tidak berbeda signifikan dengan parameter kritis teoritik. Formula optimum memiliki nilai desirability sebesar 0.878 yang mendekati 1 sehingga dapat diperkirakan bahwa pengujian terhadap parameter kritis akan memiliki hasil yang hampir sama dan tidak berbeda signifikan dengan parameter kritis hasil prediksi secara simplex lattice design menggunakan software Design Expert 10.0.1 trial version.

\section{Kesimpulan}

Berdasrkan hasil penelitian optimasi tween 80 dan etanol sebagai enhancer pada sediaan gel dispersi padat ibuprofen-PEG 6000 secara simplex lattice design dapat disimpulkan bahwa kombinasi tween 80 dan etanol sebagai enhancer atau senyawa peningkat penetrasi berpengaruh terhadap pelepasan dan peningkatan penetrasi ibuprofen pada sediaan gel dispersi padat ibuprofen-PEG 6000 dimana tween 80 lebih besar dalam meningkatkan penetrasi ibuprofen daripada etanol serta formula sediaan gel dispersi padat ibuprofenPEG 6000 menghasilkan fluks penetrasi paling optimum dengan proprosi tween 80 sebanyak $4.681 \%$ dan konsentrasi etanol sebanyak $16.319 \%$.

\section{Ucapan Terimakasih}

Ucapan terimakasih disampaikan kepada pihak Laboratorium Instrumentasi dan Teknologi Farmasi Universitas Setia Budi Surakarta tempat penilitian ini dilaksanakan, serta semua pihak yang ikut serta dalam penelitian ini.

\section{Daftar Pustaka}

Azkiya Z, Ariyani H, Nugraha TS. 2017. Evaluasi sifat fisik krim ekstrak jahe merah (Zingiber officinale Rosc. var. rubrum) sebagai anti nyeri. Journal of Current Pharmaceutical Sciences. 1(1): 12-18.

Bushra R, Aslam N. 2010. An overview of clinical pharmacology of Ibuprofen. Oman medical journal. 25(3): 155.

Durand CA, Alhammad, Willett KC. 2012. Practical considerations for optimal 
transdermal drug delivery. Am J Health Syst Pharm. 69:116-24.

Garg T, Singh S, Goyal AK. 2013. Stimulisensitive hydrogels: an excellent carrier for drug and cell delivery. Critical Reviews ${ }^{\mathrm{TM}}$ in Therapeutic Drug Carrier Systems. 30: 369-409.

Gupta R. 2020. Molecular mechanism of the skin permeation enhancing effect of ethanol: a molecular dynamics study. RSC Advances. 10(21): 12234-12248.

Handayani, S. A. (2012). Pelepasan NaDiklofenak Sistem Niosom Span 20Kolesterol Dalam Basis Gel HPMC. Pharma Scientia. 1 (2): 35.

Heard CM. 2015. Ethanol and other alcohols: old enhancers, alternative perspectives. In Percutaneous penetration enhancers chemical methods in penetration enhancement (pp. 151-172). Springer, Berlin, Heidelberg.

Nikam S. 2017. Anti-acne Gel of Isotretinoin: Formulation and Evaluation, Asian J. Pharm. Clin. Res. 10 (11):257-266.

Nurahmanto D, Mahrifah IR, Imaniah Azis RFN， Rosyidi VA. 2017. Formulasi sediaan gel dispersi padat ibuprofen: studi gelling agent dan senyawa peningkat penetrasi. Jurnal Ilmiah Manuntung. 3(1): 96-105.

Pandey A, Mittal A, Chauhan N, Alam S. 2014. Role of surfactants as penetration enhancer in transdermal drug delivery system. J Mol Pharm Org Process Res. 2(113): 2-7.

Patil UK, Saraogi R. 2014. Natural products as potential drug permeation enhancer in transdermal drug delivery system.
Archives Dermato Research. 306(5): 419-426.

Rawat S. 2011. release enhancement of meloxicam from transdermal gel through cyclodextrin complexation. Int. J. Pharm. Sci. and Res. 2(2): 357-365.

Rowe RC, Sheskey PJ, Weller PJ. 2009. Handbook of Pharmaceutical Excipients. Edisi VI. London: Publisher-Science and Practice Royal Pharmaceutical Society of Great Britain.

Saroha K, Singh S, Aggarwal A, Nanda S. 2010. Transdermal gels an alternative vehicle for drug delivery. J Pharm Chem Bio Sci. 3(3): 495-503.

Shan WY, Imam AW. 2018. Artikel tinjauan: formulasi gel ekstrak kulit manggis (Garcinia mangostana) dengan variasi konsentrasi basis. Jurnal Farmaka Suplemen. 16(1): 112-113.

Tran TT, \& Tran PH. 2020. Molecular Interactions in Solid Dispersions of Poorly Water-Soluble Drugs. Pharmaceutics.12(8): 745.

Vinklárková L, Masteiková R, Vetchý D, Doležel P, Bernatonienè J. 2015. Formulation of novel layered sodium carboxymethylcellulose film wound dressings with ibuprofen for alleviating wound pain. BioMed research international.

Yusuf AL, Nurawaliah E, Harun N. 2017. Uji Efektivitas Gel Ekstrak Etanol Daun Kelor (Moringa oleifera L.) sebagai Antijamur Malassezia furfur, Kartika: Jurnal Ilmiah Farmasi. 5 (2):62-67.

Zaini E, Nofita R, Salman, Kurniati I. 2010. Karakterisasi fisikokimia dan laju disolusi dispersi padat. J. Ris. Kim. 4(1): 25-31 